\title{
USING TAXONOMIC REVISION DATA TO ESTIMATE THE GLOBAL SPECIES RICHNESS AND CHARACTERISTICS OF UNDESCRIBED SPECIES OF DIVING BEETLES (COLEOPTERA: DYTISCIDAE)
}

\author{
VIKTOR NILSSON-ÖRTMAN AND ANDERS N. NILSSON \\ Dept. of Ecology and Environmental Science, Umeå University, SE-90187, Umeå, Sweden
}

\begin{abstract}
Many methods used for estimating species richness are either difficult to use on poorly known taxa or require input data that are laborious and expensive to collect. In this paper we apply a method which takes advantage of the carefully conducted tests of how the described diversity compares to real species richness that are inherent in taxonomic revisions. We analyze the quantitative outcome from such revisions with respect to body size, zoogeographical region and phylogenetic relationship. The best fitting model is used to predict the diversity of unrevised groups if these would have been subject to as rigorous species level hypothesis-testing as the revised groups. The sensitivity of the predictive model to single observations is estimated by bootstrapping over resampled subsets of the original data. The Dytiscidae is with its 4080 described species (end of May 2009) the most diverse group of aquatic beetles and have a world-wide distribution. Extensive taxonomic work has been carried out on the family but still the number of described species increases exponentially in most zoogeographical regions making many commonly used methods of estimation difficult to apply. We provide independent species richness estimates of subsamples for which species richness estimates can be reached through extrapolation and compare these to the species richness estimates obtained through the method using revision data. We estimate there to be 5405 species of dytiscids, a 1.32 -fold increase over the present number of described species. The undescribed diversity is likely to be biased towards species with small body size from tropical regions outside of Africa.
\end{abstract}

Key words. - Biodiversity, taxonomic bias, estimation, species richness, species description, Dytiscidae

Knowledge on the magnitude of global species richness or the relative species richness of a certain taxa in different parts of the world are essential for understanding the impact of human activities on the world's biodiversity (Purvis and Hector 2000), the factors responsible for them (Gaston 2000) and assessing the role of biodiversity in maintaining ecosystem functioning (Hooper et al. 2005). Most researchers would agree that the 1.9 million species described today (Chapman 2009) constitute a minor fraction of all the species that are out there (Gaston 1991). With the current levels of taxonomic study, certain hyperdiverse taxa might require several hundred, if not thousands of years before they are completely described (Gaston and May 1992). Thus, developing and employing efficient and imaginative analytical methods that makes the best use of the information available is essential for efficiently planning taxonomic and conservation efforts.

\section{Extrapolating from what we know}

In this paper we will focus on the concept of species richness (Gaston 1996). Estimating species richness at relevant geographic levels has been tackled in three major ways: 1) by extrapolation using the rate of species accumulation over some measure of sampling effort or in the proportion of rare species in a sample; 2) using known richness ratios of better studied taxa to infer the unknown richness of less well studied taxa, and 3) by assessing the level of underdescription based on expert opinion (Colwell and Coddington 1994).

The first method is the most frequently used method to estimate species richness at the level of a single habitat or of smaller regions (Colwell and Coddington 1994). In an analogous manner, species richness of larger areas has often been inferred by extrapolating from the rate of species description using time as a crude estimator of sampling effort. Often, more sophisticated measure of taxonomic effort is used (Dolphin and Quicke 2001). Unfortunately the assumptions of this method is violated when the number of species increases too rapidly, which is the case for many arthropod taxa. In this paper we have applied this method to a subset of species for which the assumptions are fulfilled. 
Applications of the second major strategy have proved informative in many instances (Dolphin and Quicke 2001; Adamowicz and Purvis 2005; Jones et al. 2009), but the results are sometimes highly influenced by the assumptions made by the researcher and this method has in some cases produced highly controversial results. Erwin (1982) caused much debate when he published estimates of a mindboggling 30 million arthropod species worldwide by taking the number of beetle species found in a field survey, estimating their host specificity and used this to extrapolate the total number of beetles using the much better known number of tree species in the tropics. A reanalysis of the same model using estimates of host specificity more in line with recent empirical findings (Novotny et al. 2007), gave more moderate estimates of 4.8 million arthropod species (Ødegaard 2000), In the present paper we use taxonomic ratios in a novel way by using revised groups of species as indicators of the yet undiscovered diversity of unrevised taxa.

The third approach has largely been neglected (but see Gaston 1990), but is certainly worth mentioning, since the experience of trained taxonomists acquired by working through enormous numbers of specimens must not be ignored when we assess the reliability of the 'guesstimates' reached through more or less esoteric statistical artistry.

\section{Taxonomic biases}

The data we use to estimate species richness at any level inevitably contain multiple taxonomic biases. Any outcome of field surveys or regional species lists relies on and reproduces biases found in the taxonomic literature. If the taxonomic description level differs between two taxa, these differences will likely be reflected in species counts from surveys, even if the true number of species present in a sample is the same. Unfortunately, taxonomical, geographical and trait-specific biases are common, strong and diverging (Blackburn and Gaston 1994; Colleen et al. 2004, Reed and Boback 2002). Taxonomic biases may arise through several mechanisms: some taxonomic groups have caught much more interest than others and the numbers of taxonomic workers differ between geographic regions (Gaston and May 1992) and the effort spent in different regions has changed through time (Allsopp 1997). Methodological biases such as the efficiency in which different collecting methods capture different kinds of

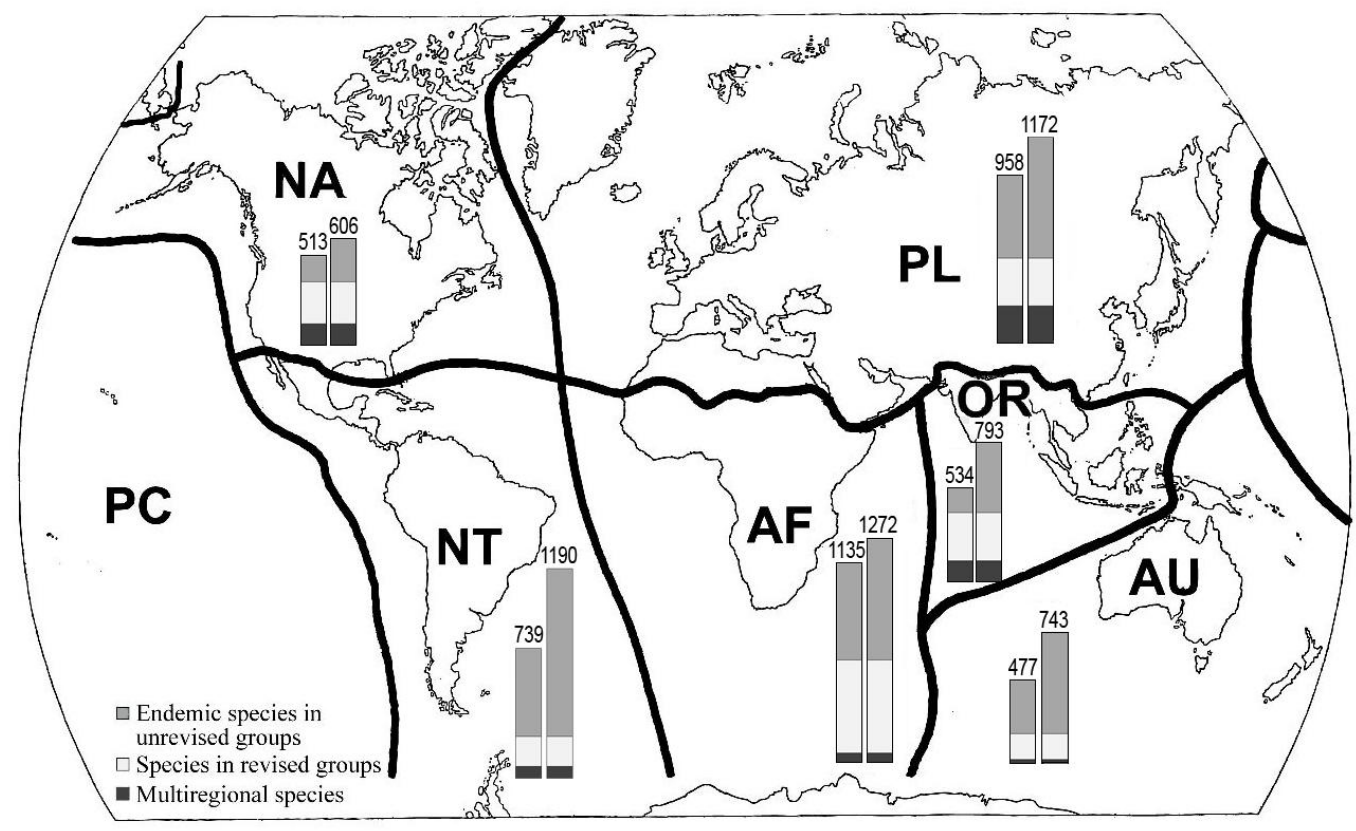

Figure 1. Delimitation of zoogeographical regions and species richness estimates. Bars show the described and predicted number of diving beetle species in each region. The left-hand bar in each pair shows the number of species considered distinct up to and including May 2009 and the right-hand bar shows the number of species predicted by the method using taxonomic revision data. The total number of species is given on top of each bar. The number of unrevised endemic, revised endemic and multiregional are indicated by different shades, see the text for details. Note that the estimation method only affects the number of species in endemic taxa which have not yet been revised. 
insects also have strong effects (King and Porter 2005). One of the stronger relationships is that smaller and less conspicuous species generally are described later. This has been shown in for example American butterflies (Gaston et al. 1995), British beetles (Gaston 1991), Western Palaearctic dung beetles (Cabrero-Sanudo and Lobo 2003), American oscine passerines (Blackburn and Gaston 1994) and carnivorous mammals (Collen et al. 2004). In some instances however, size has proved to be a poor predictor of description date. This is the case in, for example, primates (Collen et al. 2004), Australian scarabaeid beetles (Allsopp 1997), North American amphibians and reptiles (Reed and Boback 2002) and marine holozooplankton (Gibbons et al. 2005). Elucidating the effects of taxonomic biases will improve our understanding of the true patterns of diversity and help us interpret the bits and pieces of information that we have at hand.

In this paper we use data from taxonomic revisions to study the effects of taxonomic biases on the species richness of predacious diving beetles. Revisions are most often intended to counteract the disorder which builds up with time in the literature and museum collections, but we argue that they also constitute quantitative tests of how the previous level of description compares to the true species richness of a taxon. Fundamental to this approach is the hypothesis-testing nature of 'descriptive' taxonomy, which is rarely fully appreciated. Every species name is an explicitly formulated hypothesis regarding the distribution of genetic and morphological characteristics among populations of organisms (Wheeler 2004). Every time we set out to identify a specimen we test such hypotheses. Taxonomic revisions contain the summed effects of a large number of independent tests of all proposed species names applied to all available material in major museum collection. To use the outcome from taxonomic revisions for the purpose of species richness estimation was first proposed in a bachelor level thesis (Nilsson 2006), which however only dealt with a subset of the revisions analyzed here and employed rather crude statistical methods. Recently a very similar approach has successfully been used to estimate the number and distribution of undescribed species of braconid parasitic wasps (Jones et al. 2009). However, revision data is not devoid of biases. Some revisions are carried out when a large amount of new material has been collected, but a majority of revisions mostly deal with previously collected museum material (Dikow et al. 2009), so it is likely that the effect from recent collecting events will have less impact on the results, making the estimates somewhat conservative in this respect.

With 4080 described species, the Dytiscidae is the largest aquatic beetle family. Both adults and larvae of almost all species are aquatic, but pupation takes place on land. Only five species are known to be fully terrestrial. Dytiscids inhabit a wide range of both lotic and lentic freshwater habitats from $30 \mathrm{~m}$ below ground to 4,700 $\mathrm{m}$ above sea level (Jäch and Balke 2008) and no strictly marine species are known. Adults of most species are carnivorous, but may also be scavengers (Kristensen and Beutel 2005).

\section{METHODS \\ Data collection}

To collect data on the outcome of revisionary work carried out on the Dytiscidae so far, we made an exhaustive search in the Zoological Record for all publications published between 1978 and May $25^{\text {th }} 2009$ containing the word Dytiscidae together with the word revision, monograph or review in the title. This search returned 101 papers. We also searched the reference collection in the Dytiscidae Database (see below for details) for all papers published during this time span where at least 3 species where described or synonymized, expanding the list to include 129 papers which were considered in detail. For a complete list see the Appendix I. We a priori decided on the following criteria for which papers to be classified as revisions: 1) the taxonomic scope of the revision must be explicitly stated at generic or subgeneric level, 2 ) it must not be a mere faunistic review and 3) must not have supra-specific taxonomy as its main focus. After close scrutiny 88 revisions fulfilled our criteria, collectively describing 499 new species and proposing 241 new synonyms. These publications accounts for 50\% of all species described and $30 \%$ of all synonyms proposed during 1978-2009. Based on the distribution records given in the revisions, we extracted the effect the proposed taxonomic changes had on the number of species in each zoogeographical region separately. The delimitation of zoogeographical regions (or simply 'regions') used follows the most recent published version of the world catalogue of the 
Dytiscidae (Nilsson 2001). These are the Afrotropical (AF), Australian (AU), Nearctic (NE), Neotropical (NT), Oriental (OR), Pacific (PC) and Palaearctic (PL) regions (Fig. 1). From each revision we collected region-specific information on 1) the taxonomic coverage of the revision; 2) the number of separate species recognised after the revision; 3 ) the number of new species described and named; and 4) the number of species names synonymized. We calculated the number of names considered valid prior to the revision by subtracting the number of newly described species and adding the new synonymies to the number of species recognized after the revision. Most revisions treated entire genera or tribes, while some dealt with subgenera or species groups. In a few cases there were considerable overlap in the species that where revised (see for example Nilsson [1998], Štastný [2003] and Hendrich and Balke [2000], which all dealt with oriental Platynectes in the subgenus Gueorguievtes). In such cases, the results from two or three revisions were treated as a single revision and the exact number of unique species treated where carefully extracted from the original publications. From the 88 revisions, 115 observations with regional data at the genus or species group level were extracted and used for analyzing taxonomic bias in the description process. A simplified version of the dataset can be found in Appendix II. From this data we calculated the number of revised species, $\mathrm{n}_{i, k}^{\mathrm{r}}$.

A second dataset was compiled which contained data on the date of description, known global distribution divided into zoogeographical regions and mean body length (calculated as the average of minimum and maximum body length) for all 4080 species of diving beetles recognized as of May 25 $5^{\text {th }} 2009$. Body length data was only missing for four species which were excluded from the analysis. This dataset was used for summarizing the final species richness estimated using revision data, to extrapolate from the rates of taxonomic description and to explore patterns in the current and historical knowledge of the Dytiscidae. Information for this dataset was collected from the Dytiscidae Database assembled by A.N. while working with the World Catalogue of Insects volume on Dytiscidae (Nilsson 2001). Its information is drawn directly from original sources and studies of type material and includes information on type locality, type depository, global distribution, notes on synonymy and body length of all dytiscid taxa. The database is continuously kept updated and information from all taxonomic publications published before the end of May 2009 has been included in this analysis.

\section{Method I: Using taxonomic revision data}

This method assumes that the taxonomic revisionary process is a random process insofar as the groups of species subject to revisions are selected effectively at random. We further assume that revised groups approach their true diversity after a revision has been carried out. The second assumption is likely to be frequently violated, causing the method to underestimate the true diversity. Neither of these assumptions has to our knowledge been subject to any scientific study but certainly merits closer examination.

We used gamma Generalized linear models (GLM) with log link function (Faraway 2004) to analyze the outcome of the taxonomic revisions. We used the $\log _{\mathrm{e}}$-transformed ratio between the number of species considered valid after and before the revision as our response variable and zoogeographical region, body length and taxonomic group as additive predictor variables. The non-normal distribution of the response variable and body length data motivated the use of GLM, which does not assume that the variables are normally distributed (McCullagh and Nelder 1989).

Ratio data, being one random value divided by another random value, have rather unique statistical properties. Assuming that data from taxonomic revisions represent randomly drawn observations on the level of underdescription of a taxon, the outcome of revisions form a rather distinct class of data where we do not expect that large values of the denominator (the number of species before) necessarily dictate large values of the nominator (the number of species after). Such data can be modelled as two independent gamma random variables with the ratio of these being non-normal and the relationship between nominator and denominator being weak (Liermann et al. 2004), an approach which we have adopted here. All statistical analyses were made using $\mathrm{R}$ version 2.9 .0 with the $1 \mathrm{me} 4$ and sampling packages.

Another bias which may be found is that the revision data that we use to reach our estimates mostly reflect the large amount of specimens 
that are already collected, but hidden among poorly examined museum material, and only to a lesser extent reflect what happens when new material is collected from previously undersampled areas. As more and more remote areas are sampled, the pattern, and especially the magnitude of the undescribed diversity may change although the 88 revisions considered in this paper offer a window into this great unknown.

For the taxonomic groupings used to investigate taxonomic biases, we decided not to use the ten dytiscid subfamilies as this would fail to capture any information on taxonomic biases found within the largest subfamily, Hydroporinae, which encompass well over half of the world's diving beetle species. Instead, we constructed a taxonomic framework based on the following criteria: 1) the chosen groups should have support from molecular data while not severely violating the traditionally used classification, 2) include the vast majority of described species, and 3) preferably be treated in a fairly equal number of revisionary works. Using these criteria we decided on a phylogenetic framework containing 7 groups corresponding to either subfamilies or tribes, collectively containing more than $95 \%$ of all dytiscid species and all revised taxa. These groups were: 1) Bidessini+Pachydrini; 2) Colymbetinae sl., including Agabinae, Colymbetinae and Dytiscini, chiefly corresponding to lineage 2 in the PR alignment of Ribera et al. (2008); 3) Copelatinae sl. (sensu Ribera et al. [2008]); 4) Hydaticini sl. (sensu Ribera et al. [2008], eg. Dytiscinae excluding Dytiscini); 5) Hydroporini sl. (sensu Ribera et al. (2008); 6) Hydrovatini+Vatellini and 7) Laccophilini. These groupings generally had strong molecular support from Ribera et al.'s (2008) phylogenic analysis. In their analysis they used four gene fragments with a combined length of about 4000 aligned base pairs and performed separate analyses using three different sequence alignments. In their Bayesian analyses, almost all the groupings listed above had posterior probabilities (PP) above 0.90 in two or more of these alignments. There are two exceptions to this, however. One is the Colymbetinae sl., which mostly contain large, bulky species. A monophyletic origin was strongly supported by just one of the alignments. However, internal relationships between these taxa were always poorly resolved, and they were consistently placed basal to other taxa. We feel that morphology and molecular data taken together lends sufficient support for treating them together in this context. The second exception is the very diverse assemblage Hydroporini sl. This grouping had moderate support, with PP of 0.90 and 0.50 from two alignments, respectively, but this uncertainty is mainly caused by difficulties resolving the placement of a few associated species-poor genera. These taken together, Hydroporini.sl form a sister group to the two well supported groups Bidessini+Pachydrini and Hydrovatini+Vatellini, effectively splitting the huge subfamily Hydroporinae into two subequal halves, and the second and third criterion is thus well fulfilled.

The regional coverage among the 115 outcomes of revisions on the regional level where as follows: Afrotropical 19 (16.67\%), Australian 11 (9.65\%), Nearctic 26 (22.81\%), Neotropical 14 (12.28\%), Oriental 15 (13.16\%) and Palaearctic 28 (24.56\%). The taxonomic coverage was: Bidessini+Pachydrini 21 (18.42\%), Colymbetinae sl. 26 (22.81\%), Copelatinae sl. 6 (5.26\%), Hydaticini sl. 5 (4.38\%), Hydroporini sl. 42 (36.84\%), Hydrovatini+Vatellini $9 \quad(7.89 \%)$ and Laccophilini 5 (4.39\%).

\section{Predicting the unrevised diversity}

The GLM model fitted to the revision data was used to predict the hypothetical $\log _{\mathrm{e}}$ (after/before) outcome of future revisions of all genera. The back-transformed after/before ratio was used to correct regional species richness for biases attributable to differences in body size, taxonomic group and zoogeographical region. To calculate the absolute effects the predictive model had on regional species richness, we first had to address two questions: the species richness of genera which have already been revised must not be corrected one more time and the number of species occurring on multiple continents should not be counted in each region separately, which would inflate the number of species predicted by this approach. To deal with these issues we partitioned the regional species richness of each genus into three components: revised endemic species, unrevised endemic species and multiregional species. From the revision dataset described above we counted the number of species in each genus which had been subject to 
at least one taxonomic revision within the defined time span, $\mathrm{n}_{i, k}^{\mathrm{r}}$. Then we calculated the number of unrevised endemic species, $\mathrm{n}_{i, k}^{\mathrm{u}}$, by assuming that species occurring in one or more zoogeographical regions are equally likely to be included in the taxonomic revisions, so that we for each genera $i$ and region $k$ get:

$$
\mathrm{n}_{i, k}^{\mathrm{u}}=\mathrm{n}_{i, k}^{\mathrm{e}}-\left(\frac{\mathrm{n}_{i, k}^{\mathrm{r}}}{\mathrm{n}_{i, k}} \cdot \mathrm{n}_{i, k}^{\mathrm{m}}\right),
$$

where $\mathrm{n}_{i, k}^{\mathrm{e}}$ is the number of endemic species, $\mathrm{n}_{i, k}^{\mathrm{r}}$ is the total number of species revised, $\mathrm{n}_{i, k}$ is the total number of species and $\mathrm{n}_{i, k}$ is the number of multiregional species. This way our total diversity estimate was given by:

$\mathrm{n}^{\text {total }}{ }_{i, k}=\mathrm{n}_{i, k}^{\mathrm{m}}+\mathrm{n}_{i, k}^{\text {rev.end }}+\mathrm{n}_{i, k}^{\mathrm{u}} \cdot$ multiplier(predicted) (Eq.2)

where $\mathrm{n}_{i, k}^{\text {rev.end }}$ is the number of revised endemic species.

To produce error estimates of the predicted outcomes and avoid biases from outlier observations, we carried out these predictions using a stratified resampling approach. In each resampling round, $80 \%$ of the observations from each of the seven taxonomic groups were sampled without replacement from the original revision dataset. This subset of observations was used to construct a new GLM model which predicted the $\log _{\mathrm{e}}$ (after/before) ratio of unrevised groups, given the known region, body length and taxonomic group. The predicted logarithmic outcome ratios of all genera were backtransformed and multiplied with the number of unrevised species in each genus. The total predicted diversity was then calculated using Equation 2. In each round we calculated the following summary statistics: 1) species richness of each genus, 2) species richness of each subfamily, 3) predicted global diversity of diving beetles, and 4) GLM model summary statistics. The stratified resampling routines were written in the statistical computer language R (R Development Core Team 2007).

The three species poor tribes Hydrodytini (4 species) Lancetini (22 species) and Matini (8 species) form a sister group to the rest of the Colymbetinae sl. as defined above (Ribera et al. 2008). They were excluded from the estimation model based on their remarkably low speciation rate compared to the other taxa in this group.
Seven genera with uncertain positions within the Hydroporinae were also excluded from the analysis: Hydrodessus (17), Kuschelydrus (1), Morimotoa (3), Pachydrus (9), Phreatodessus (2), Terradessus (2), Typhlodessus (1), and Agabetini (2). No revisions dealt with any group of species within Cybistrini. These have traditionally been placed in the Dytiscinae, with which they share the generally large body size, but Ribera et al. (2008) showed that they are closer to the generally much smaller Hydroporinae. Treating this group with either Dytiscinae or Hydroporinae both seemed rather spurious. Thus, the 134 cybistrine species were excluded from the estimation procedure. Uncorrected figures of the number of species from all excluded groups are presented in the total species richness summaries. When data from Balke's (1998) revision of New Guinean Exocelina, where the number of species increased by a factor of 16.5 from 2 to 33 species, was included in the analysis, the bootstrap did not converge. This observation was therefore excluded from the analysis.

\section{Method II: rates of taxonomic description}

In many instances, the process of taxonomic description proceeds in a manner very similar to the accumulation of new species caught in local biodiversity surveys with constant sampling effort over time. The similarity between these two classes of data is frequently used to justify the estimation of the magnitude of global species richness using data from the species description process in the same manner as estimations of local species richness (Colwell and Coddington 1994). However, the two types of data differ in several aspects. To be able to use species description data for this purpose, we must have considered that: 1) the effort spent on taxonomic discovery and description varies greatly over time and between regions; 2) curves showing the rate of description plotted against time often displays a distinct "lag phase" of low description rates in the initial stage; 3) the precise relationship between taxonomic effort and description rate is poorly understood, making it difficult to justify which model to fit to the data; 4) the description process frequently proceed in pronounced leaps marking the publication of important monographic works and revision which are impossible to predict using extrapolation techniques; 5) if there is no sign of decrease in the rate of description over 
time, extrapolating techniques cannot be applied (White 1979). This restricts the usage of such techniques to better studied taxa which likely are not very good representatives of the great majority of the world's taxa.

We explored for which groups of diving beetles this approach can be applied and used the species richness estimates of those groups to corroborate the results from the estimates reached using the method with revision data. We dealt with the uneven taxonomic effort by considering the varying number of taxonomic workers active at any point in time and standardizing the description rate against this index. Following Dolphin and Quicke (2001), we defined the term "prospective description rate" as the number of species described for every 20 taxonomist-years. The "lag phase" of low description rates in the initial stage of species description is usually ascribed to the process of taxonomic organization, when much effort is required for discovering morphological features useful for species delimitation and developing a systematic framework above the species level in which to incorporate species (O'Brien and Wibmer 1979). Sometime after this step the rate of description usually reaches its maximum and the effort required for the discovery of new species is at its lowest. Provided that this is an adequate description of the lag-phase, we can assume that it contains little information about the magnitude of global species richness and avoid the problems inflicted by it by excluding data from the lag phase from our analysis and consider only the data from after the time when the description rate reached its highest level. Plotting the prospective description rate against the number of species described, we expect a negative, linear relationship where the amount of work required for the discovery of new species steadily increases, and the prospective description rate decreases, as more and more species are described. Fitting a linear model to such data, the $\mathrm{x}$-intercept of the regression will provide us with an estimate of the number of species described when the description rate is zero.
Using the data from the Dytiscidae Database, we compiled a list of all taxonomists that have described at least one dytiscid species, now considered distinct. For each author we noted to which zoogeographical regions and dytiscid subfamilies the described species belong to. We also noted the publication date of the first and last species described, taking the period between these dates as the active period of each author. From this information we calculated the cumulative taxonomic effort that had been invested for each taxon and region and the number of species described in each 20 taxonomist-year. We also tested whether there were a relationship between body length and the date of description in diving beetles. Neither body length nor date of description was normally distributed (Shapiro-Wilk test, data not shown), therefore Kruskal-Wallis rank sum test was used.

\section{RESULTS}

Outcome of taxonomic revisions

Of the 4080 dytiscid species described today, 1644 have been critically examined as part of a taxonomic revision during the last 31 years. In the 88 revisions analyzed, the ratio of the number of species recognized after and before the revision increased on average by a factor of 1.65. If we would apply this correction factor directly to the 2352 endemic species that were not covered by these revisions, we would reach an estimate of the global diversity of diving beetles at about 5822 species, constituting an 1.43 -fold increase. However, modelling the outcome of taxonomic revisions as a function of size, distribution and taxonomic group allowed us to correct for these biases, providing us with much more precise estimates.

The full GLM model analyzing the outcome of taxonomic revisions using the full revision dataset had an Nagelkerke pseudo- $\mathbf{R}^{2}$ (Nagelkerke 1991) of 0.30 and both region $\left(\chi^{2}=19.96\right.$, d.f. $\left.=5, \mathrm{p}=0.001\right)$ and body length $\left(\chi^{2}=6.988793\right.$, d.f. $\left.=1, p<0.001\right)$ were significant while the effect of taxonomic groups was not $\left(\chi^{2}\right.$ $=10.81001$, d.f $=6, p=0.0944$ ). 


\begin{tabular}{|c|c|c|c|c|c|}
\hline Region & Subfamily & Multiregional & Endemic & Predicted & Multiplier \\
\hline \multirow{7}{*}{$\mathbf{A F}$} & Agabinae & 0 & 13 & $13(12.77-13.13)$ & 1.00 \\
\hline & Colymbetinae & 0 & 15 & $15(13.46-16.31)$ & 1.00 \\
\hline & Copelatinae & 4 & 227 & $301(233.27-363.88)$ & 1.33 \\
\hline & Dytiscinae & 16 & 111 & $95(88.75-100.28)$ & 0.86 \\
\hline & Hydroporinae & 34 & 581 & $618(611.17-624.73)$ & 1.06 \\
\hline & Laccophilinae & 2 & 132 & $170(114.25-224.14)$ & 1.29 \\
\hline & Agabinae & 2 & 15 & $26(21.03-32.87)$ & 1.73 \\
\hline \multirow{6}{*}{$\mathbf{A U}$} & Colymbetinae & 2 & 22 & $31(25.96-35.67)$ & 1.41 \\
\hline & Copelatinae & 2 & 91 & $161(121.40-206.92)$ & 1.77 \\
\hline & Dytiscinae $^{1}$ & 7 & 34 & $52(34.96-100.81)$ & 1.53 \\
\hline & Hydroporinae & 8 & 266 & $405(348.97-473.00)$ & 1.52 \\
\hline & Laccophilinae & 5 & 24 & $31(29.51-32.70)$ & 1.29 \\
\hline & Lancetinae & 0 & 1 & 1 (not predicted) & 1.00 \\
\hline \multirow{10}{*}{ NA } & Matinae & 0 & 4 & 4 (not predicted) & 1.00 \\
\hline & Agabinae & 26 & 92 & $122(119.62-124.85)$ & 1.33 \\
\hline & Colymbetinae & 8 & 13 & $16(15.24-17.59)$ & 1.23 \\
\hline & Copelatinae & 2 & 2 & $3(2.22-3.58)$ & 1.50 \\
\hline & Coptotominae & 2 & 3 & $4(3.05-4.98)$ & 1.33 \\
\hline & Dytiscinae $^{1}$ & 17 & 24 & $25(24.60-26.03)$ & 1.04 \\
\hline & Hydrodytinae & 0 & 1 & 1 (not predicted) & 1.00 \\
\hline & Hydroporinae & 58 & 245 & $296(279.92-314.39)$ & 1.21 \\
\hline & Laccophilinae & 12 & 4 & $5(3.87-6.61)$ & 1.25 \\
\hline & Matinae & 0 & 4 & 4 (not predicted) & 1.00 \\
\hline \multirow{7}{*}{ NT } & Agabinae & 0 & 40 & $70(58.35-81.06)$ & 1.75 \\
\hline & Colymbetinae & 4 & 25 & $40(33.27-46.18)$ & 1.60 \\
\hline & Copelatinae & 2 & 129 & $275(209.15-339.41)$ & 2.13 \\
\hline & Coptotominae & 2 & 0 & 0 (not predicted) & 1.00 \\
\hline & Dytiscinae $^{1}$ & 13 & 51 & $56(53.08-59.34)$ & 1.10 \\
\hline & Hydrodytinae & 0 & 3 & 3 (not predicted) & 1.00 \\
\hline & Hydroporinae & 38 & 328 & $449(409.55-482.62)$ & 1.37 \\
\hline \multirow{9}{*}{ OR } & Laccophilinae & 11 & 89 & $185(115.40-256.07)$ & 2.08 \\
\hline & Lancetinae & 0 & 21 & 21 (not predicted) & 1.00 \\
\hline & Agabinae & 4 & 18 & $25(23.66-26.82)$ & 1.39 \\
\hline & Colymbetinae & 2 & 4 & $8(6.41-8.76)$ & 2.00 \\
\hline & Copelatinae & 14 & 97 & $164(141.05-193.17)$ & 1.69 \\
\hline & Dytiscinae $^{1}$ & 34 & 49 & $63(56.61-70.16)$ & 1.29 \\
\hline & Hydroporinae & 46 & 145 & $243(211.83-274.97)$ & 1.68 \\
\hline & Laccophilinae & 22 & 99 & $155(132.60-180.28)$ & 1.57 \\
\hline & Agabinae & 28 & 187 & $232(214.96-251.91)$ & 1.24 \\
\hline \multirow{4}{*}{ PL } & Colymbetinae & 6 & 40 & $46(39.51-50.32)$ & 1.15 \\
\hline & Copelatinae & 17 & 27 & $44(37.02-50.14)$ & 1.63 \\
\hline & Dytiscinae $^{1}$ & 49 & 43 & $43(41.69-44.89)$ & 1.00 \\
\hline & Hydroporinae & 91 & 430 & $535(490.31-579.32)$ & 1.24 \\
\hline \multirow{6}{*}{ PC } & Laccophilinae & 21 & 21 & $37(33.13-41.68)$ & 1.76 \\
\hline & Colymbetinae & 1 & 9 & 9 (not predicted) & 1.00 \\
\hline & Copelatinae & 0 & 1 & 1 (not predicted) & 1.00 \\
\hline & Dytiscinae & 1 & 1 & 1 (not predicted) & 1.00 \\
\hline & Hydroporinae & 0 & 2 & 2 (not predicted) & 1.00 \\
\hline & ${ }^{1}$ Including $\mathrm{Cy}$ & e text) & & & \\
\hline
\end{tabular}

Table 1. Species richness of diving beetle subfamilies divided into zoogeographical regions. Shown are the number of species which occur in more than one zoogeographical region, the numbers of named, distinct species known only from a given region, the estimated number of endemic species when we correct for taxonomic biases using the outcome of taxonomic revisions and the relative increase of species richness this constitutes. 
Our best estimate of the global species richness of diving beetles is 5405 species $(95 \%$ assymetrical quartiles $=$ [5086-5661] $)$, which we reached by carrying out 10.000 bootstrap replicates using a random subset of the revision data (Table 1). This constitutes a 1.25 to 1.39 fold increase in the number of species compared to the number of species known today. The largest relative regional increases are found in the Neotropic (1.61-fold increase, 95\% quantiles [1.42-1.81]), Australian (1.56-fold increase, 95\% quantiles [1.34-1.83] and Oriental (1.49-fold increase, 95\% quantiles [1.36-1.62]) regions, while the increase is less pronounced in the Palaearctic (1.22-fold increase, 95\% quantiles [1.15-1.29]), Nearctic (1.18-fold increase, 95\% quantiles [1.15-1.23]) and African (1.12-fold increase, 95\% quantiles [1.02-1.21]) regions (Fig 1). This has some minor effects on our understanding on the distribution of diversity among the zoogeographical regions. The Neotropical region surpasses the Palaearctic region as the second most species rich region following the Afrotropical and it suggest that the least diversity is actually found in the Nearctic region, not in the Australian as the distribution of the currently described diversity suggest.

Among the subfamilies of Dytiscidae, the largest relative increases are expected among the Copelatinae (1.63-fold increase, 95\% quantiles [1.32-1.91]) and Laccophilinae (1.49-fold increase, 95\% quantiles [1.13-1.85]), while for the Agabinae (1.31-fold increase, 95\% quantiles [1.25-1.37]), Hydroporinae (1.24-fold increase, 95\% quantiles [1.21-1.30]), Colymbetinae (1.23fold increase, 95\% quantiles [1.05-1.25]) and Dytiscinae (1.06-fold increase, 95\% quantiles [1.00-1.19]) the increases are less dramatic (Table 1). These changes have no effect on the species richness rank-order between subfamilies.

\section{Rates of description}

Since 1758, when Linnaeus described the first diving beetle, 308 taxonomists have spent 2491 taxonomist-years describing the 4080 currently recognized dytiscid species. The description rate reached its maximum around the end of the $19^{\text {th }}$ century for most taxa and regions, to a great extent due to the work of two individual taxonomists, Maurice Régimbart and David Sharp, who described a most remarkable number of species from all continents between 1870 and 1910, of which 754 are still considered distinct

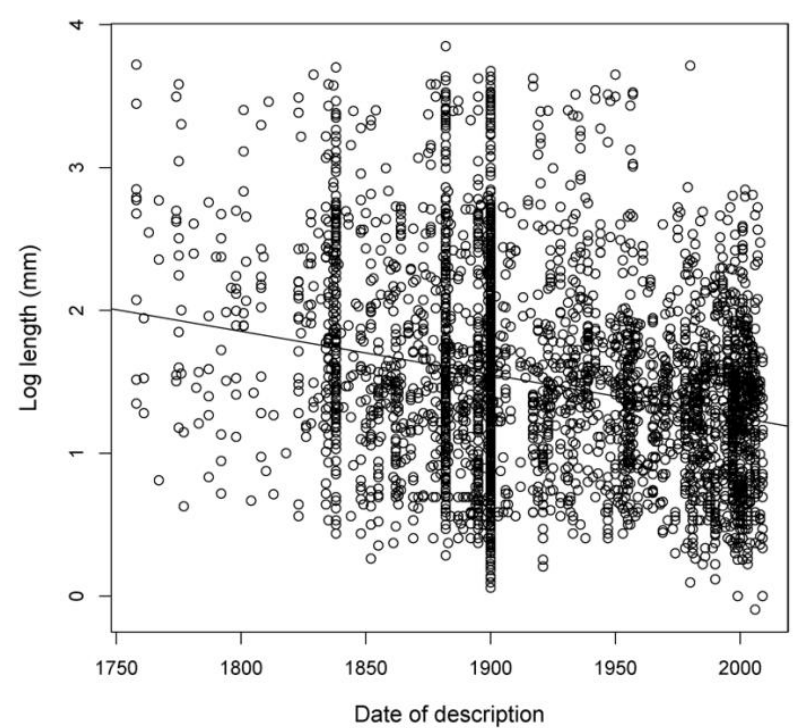

Figure 2. Relationship between a species' date of description and its body length for diving beetles. Note that the $y$-axis is $\log$ transformed to show smaller species better.

today. For the family as a whole, there is a significant relationship between body length and date of description $\left(\mathrm{r}^{2}=0.057, \mathrm{P}<0.0001\right)$ (Fig 2). This decline in body size of described species over time is consistent across different time periods, with the correlation being equally strong between the years 1758-1865 $\left(\mathrm{r}^{2}=0.047\right.$, $\mathrm{n}=540, \mathrm{p}<0.0001)$ and $1910-2009\left(\mathrm{r}^{2}=0.044, \mathrm{n}\right.$ $=1756, \mathrm{p}<0.0001)$.

Four zoogeographical regions and two subfamilies show signs of approaching saturation (Fig 3). The Oriental region showed no signs of saturation and the Australian region even display a significant, positive trend in the prospective description rate $\left(\mathrm{r}^{2}=0.242\right.$, $\mathrm{p}=0.005$ ) suggesting that this region is in a highly intensive phase of the descriptive process. By fitting a linear model to these groups of taxa and calculating the number of species described when the linear predictor of description rate was zero we calculated the final species richness of these groups. The estimate reached this way were generally directly comparable with the results gained from the method using revision data and the slope of the regression $(1.15 \pm 0.4)$ was very close to 1 (Fig 4). The major difference is that the estimates from the revision data method predict distinctly more undescribed species in the Neotropical region, while the 

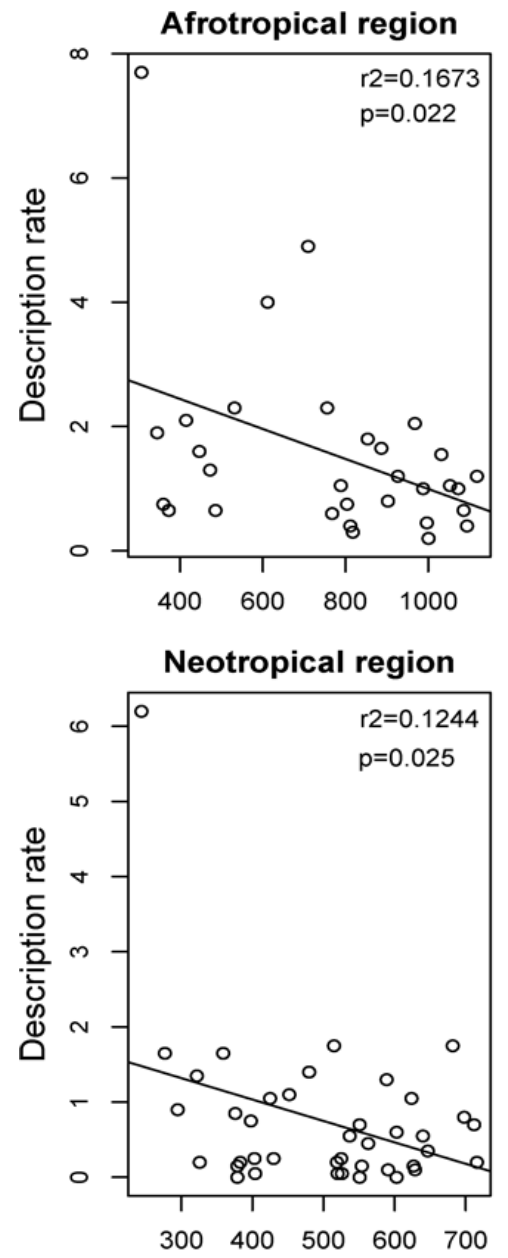

N. species described
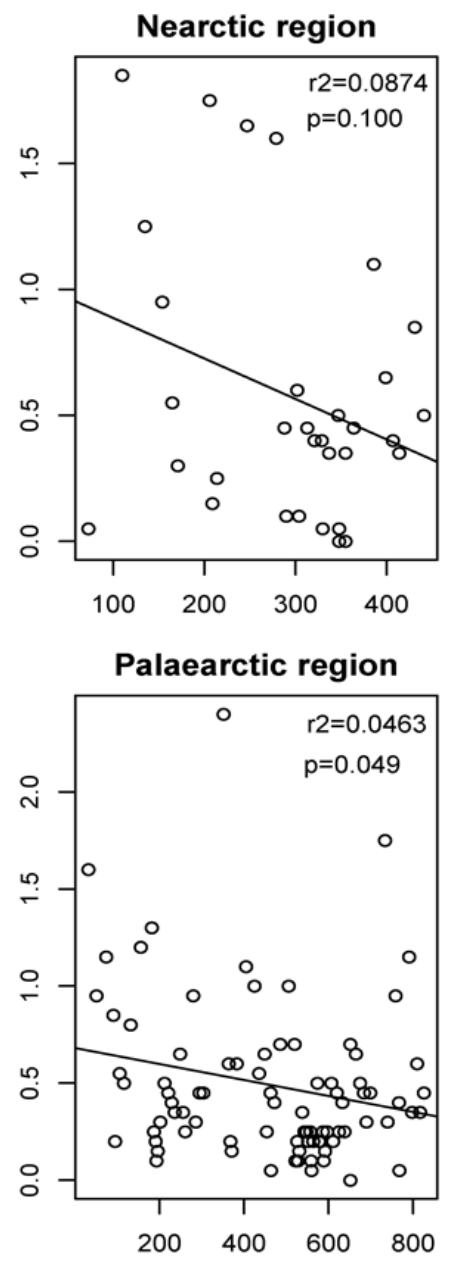

N. species described
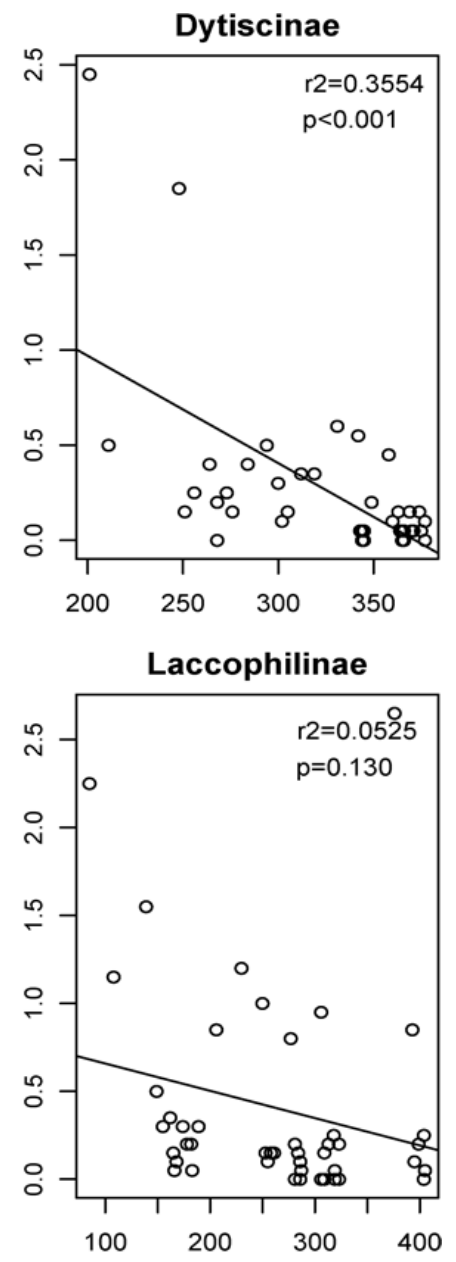

N. species described

Figure 3. Rate of description of new dytiscid species (number of species per 20 taxonomist-year) plotted against the number of species already described at the same time for the four regions and two subfamilies showing signs of decreased description rates. The lines show linear models fitted to the data and the associated $\mathrm{R}^{2}$ and $\mathrm{p}$-values of the models are shown in the upper right corner.

description rate method predicted larger increases in the Palaearctic.

\section{DISCUSSION}

We have shown that even for a comparatively well studied arthropod taxon such as the Dytiscidae, there is a considerable number of species still undescribed. We estimate there to be 5404 dytiscid species in the world, compared to the 4080 known today. This estimate compares rather well with previous estimates of 5000 species based on expert opinion (Jäch and Balke 2008) and constitutes a rather modest 1.32-fold increase. There were clear patterns regarding the characteristics of the 1324 species predicted to remain undescribed. The undescribed diversity is likely to be biased toward smaller species from tropical regions outside of Africa. Compared to the only other study that have used a comparable method, which applied it to braconid parasitic wasps (Jones et al. 2009), taxonomic biases in the Dytiscidae differs in one striking aspect: while the greatest number of undescribed species was predicted to be found in the Afrotropical region for braconid wasps, our study suggest that for diving beetles the Afrotropical region will experience the smallest relative increase. It is possible that these diverging patterns are artefactual, demonstrating biases in which groups are chosen for revision in different regions. The alternative explanation is that this reflects true differences between taxa caused by historical and biological factors. In Dytiscidae, 
Afrotropical taxa were represented by 19 revisions, covering $46 \%$ of the region's fauna. All these cases displayed uniformly weak responses to revisions and the number of species increased on average by a factor of 1.075 . In only a single case (Clypeodytes: Biström 1988) a taxon increased as much as 1.6-fold. This is further supported by the correlation between estimates for the Afrotropical fauna reached by the two independent methods (Fig. 3 and Fig. 4). Taken together, the dytiscid fauna of the Afrotropical region indeed appears to be well studied and suggests that we should be cautious not to make simplistic statements about the level of unknown diversity in the tropics.

Compared to the methods used in the Jones et al. (2009) paper, the present study most importantly differ in that we avoid applying the correction factors multiple times to already revised taxa by making a distinction between revised and unrevised taxa as well as between endemic and multiregional species when calculating the effects the predictive model has on the global species richness estimates. We feel that these distinctions are important, especially with regard to taxa where a non-negligible portion of the species pool has been subject to revision.

The exclusion of multiregional species constitutes a potential pitfall with this method. Doing this does not take into account that many multiregional species may constitute several, cryptic, sibling species, which are sometimes identified in taxonomic revision. As an example, Adamowicz and Purvis (2005) found that $64.3 \%$ of branchiopod species believed to have multiregional distributions de facto represented two or more genetically well separated species when studied in more detail. But since multiregional species constitute a small proportion of the total diversity of diving beetles, and in several cases merely represent the artificial nature of delimitating zoogeographical regions, we argue that treating the number of multiregional species as fixed is unlikely to have a major impact on the final results.

The approach we have adopted here offers the potential to correct for a range of biases influencing our knowledge on the distribution of biodiversity. To give an idea of the extent of the taxonomic literature which could be utilized for this purpose, a literature search by Meier and Dikow (2002) found that more than 2300 zoological revisions were published between

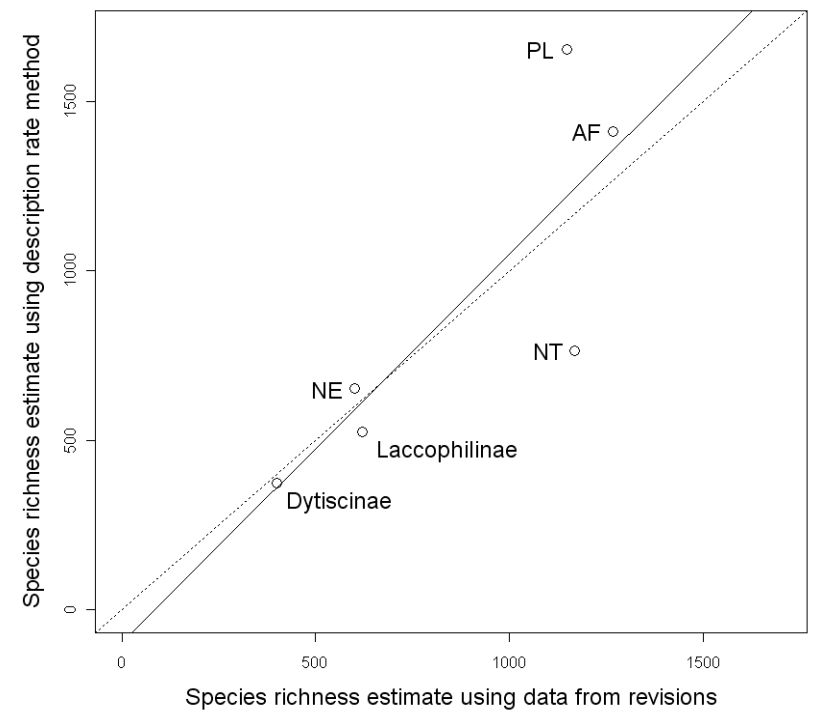

Figure 4. Comparison between the number of species predicted by the method using taxonomic revision data and the results using the rate of description of groups showing signs of saturation. Regression over the observed data (solid line) falls very close to a constant ratio of 1 (dashed line).

1990 and 2002. Given the success of the two attempts to utilize this information carried out so far, we believe that if this method is applied to a broader range of taxa, possibly incorporating additional explanatory variables, we will gain much insight into the magnitude and distribution of species richness which will help us focus taxonomic expertise and funding into areas where they are most needed.

\section{REFERENCES}

Allsopp, P.G. 1997. Probability of describing an Australian scarab beetle: influence of body size and distribution. Journal of Biogeography, 24(6), 717-724.

Adamowicz, S.J. and Purvis, A. 2005. How many branchiopod crustacean species are there? Quantifying the component of underestimation. Global Ecology and Biogeography 14: 455-468.

Balke, M. 1998. Revision of New Guinea Copelatus Erichson, 1832 (Insecta: Coleoptera: Dytiscidae): The running water species, Part I. Annalen des Naturhistorischen Museum in Wien (B) 100: 301341.

Biström, O. 1988. Revision of the genus Clypeodytes Régimbart in Africa (Coleoptera: Dytiscidae). Entomologica Scandinavica 19: 199- 238.

Blackburn, T. and Gaston, K. 1994. Animal bodysize distributions change as more species are 
described. Proceedings of the Royal Society of London Series B 257: 293-297.

Cabrero-Sanudo, F. and Lobo, J. 2003. Estimating the number of species not yet described and their characteristics: the case of Western Palaearctic dung beetle species (Coleoptera, Scarabaeoidea). Biodiversity and Conservation, 12, 147-166.

Chapman, A.D. 2009. Numbers of Living Species in Australia and the World. Report for the Australian Biological Resources Study. Canberra, Australia.

Collen, B., Purvis, A. and Gittleman, J. 2004. Biological correlates of description date in carnivores and primates. Global Ecology and Biogeography, 13, 459-467.

Colwell, R.K. and Coddington, J.A. 1994. Estimating terrestrial biodiversity through extrapolation. Philosophical Transactions of the Royal Society (Series B). 345:101-118.

Dikow, T., Meier, R., Vaidya, G.G. and Londt, J.G.H. 2009. Biodiversity research Based on taxonomic revisions - a tale of Unrealized opportunities. In: Diptera Diversity: Status, Challenges and Tools. (eds Pape, T., Bickel, D. and Meier, R.). Koninklijke Brill NV, Leiden.

Dolphin, K. and Quicke, D. 2001. Estimating the global species richness of an incompletely described taxon: an example using parasitoid wasps (Hymenoptera : Braconidae). Biological Journal of the Linnean Society 73(3): 279-286.

Erwin, T.L. 1982. Tropical forests: their richness in Coleoptera and other arthropod species. The Coleopterists Bulletin 36: 74-75.

Faraway, Julian. 2005. Extending the Linear Model with R: Generalized Linear, Mixed Effects and Nonparametric Regression Models. Chapman and Hall. Boca Raton, USA.

Gaston, K.J. 1991. The magnitude of global insect species richness. Conservation Biology. 5(3): 283-296.

Gaston, K.J. 1996. Species richness, measure and measurement. In: Biodiversity (ed. by Gaston, K.J.). 77-113. Blackwell Science, Oxford, U.K.

Gaston, K.J., 2000. Global patterns in biodiversity. Nature, 405(6783): 220-227.

Gaston, K.J., Blackburn, T. and Loder, N. 1995. Which species are described first - the case of north-american butterflies. Biodiversity and Conservation 4(2): 119-127.

Gaston, K.J. and May, R.M. 1992. Taxonomy of taxonomists. Nature 356(6367): 281-282.

Gibbons, M. J., Richardson, A. J., Angel, M. V., Buecher, E., Esnal, G., Fernandez Alamo, M. A. Gibson, R., Itoh, H., Pugh, P., Boettger-Schnack, R. and Thuesen, E. 2005. What determines the likelihood of species discovery in marine holozooplankton: is size, range or depth important? Oikos 109: 567-576.
Hendrich, L. and Balke, M. 2000. The genus Platynectes Régimbart in the Moluccas (Indonesia): taxonomy, faunistics and zoogeography (Coleoptera: Dytiscidae). Koleopterologische Rundschau 70: 37-52.

Hooper, D.U., Chapin, F.S., Ewel, J.J., Hector, A., Inchausti, P., Lavorel, S. et al. 2005. Effects of biodiversity on ecosystem functioning: a consensus of current knowledge. Ecological Monographs 75(1), 3-35.

Jones, O.R., Purvis, A., Baumgart, E. and Quicke, D.L.J. 2009. Using taxonomic revision data to estimate the geographic and taxonomic distribution of undescribed species richness in the Braconidae (Hymenoptera: Ichneumonoidea). Insect Conservation and Diversity 2(3): 204-212.

Jäch, M.A. and Balke, M. 2008. Global diversity of water beetles (Coleoptera) in freshwater. Hydrobiologia 595: 419-442.

King, J. and Porter, S., 2005. Evaluation of sampling methods and species richness estimators for ants in upland ecosystems in Florida. Environmental Entomology 34(6), 1566-1578.

Kristensen, N.P. and Beutel, R.G. 2005. Handbook of Zoology Volume IV: Arthropoda: Insecta, Volume 1: Morphology and Systematics (Archostemate, Adephaga, Myxophaga, Polyphaga partim) Part 38. New York: Walter de Gruyter.

Liermann, M., Steel, A., Rosing, M. and Guttorp, P. 2004. Random denominators and the analysis of ratio data. Environmental and Ecological Statistics 11: 55-71.

McCullagh, P. and Nelder, J. A. 1989. Generalized linear models (2nd ed.). Chapman and Hall. London, UK.

Meier, R., and Dikow, T. 2002. Significance of specimen databases from taxonomic revisions for estimating and mapping the global species diversity of invertebrates and repatriating reliable specimen data. Conservation Biology 18(2): 478488.

Nagelkerke, N.J.D. 1991. A note on a general definition of the coefficient of determination. Biometrika, 691-692.

Nilsson, A.N. 1998. Dytiscidae: V. The genus Platynectes Regimbart in China, with a revision of the dissimilis-complex (Coleoptera). In: Water Beetles of China III (eds. Jäch, M.A. and Li, J.). 107-121.

Nilsson, A.N. 2001. Dytiscidae - In: World Catalogue of Insects 3: 1-395. Apollo Books, Stenstrup, Denmark.

Nilsson, V.J. 2006: Using taxonomic data to estimate species diversity: A multivariate approach applied to diving beetles (Coleoptera: Dytiscidae). Bachelor's thesis. Umeå University. 
Novotny, V., Miller, S.E., Hulcr, J. Drew, R.A.I., Basset, Y. Janda, M. et al. 2007. Low beta diversity of herbivorous insects in tropical forests. Nature 448(7154): 692-695.

O'Brien, C.W., and Wibmer, G.J. 1979. The use of trend curves of rates of species descriptions: examples from the Curculionidae (Coleoptera). The Coleopterists' Bulletin: 151-166.

Purvis, A. and Hector, A. 2000. Getting the measure of biodiversity. Nature 405(6783): 212-219.

R Development Core Team. 2007. R: a language and environment for statistical computing. R Foundation for Statistical Computing, Vienna, Austria.

Ribera, I., Vogler, A.P., and Balke, M. 2008. Phylogeny and diversification of diving beetles (Coleoptera: Dytiscidae). Cladistics 24(4): 563590

Reed, R.N. and Boback, S.M. 2002. Does body size predict dates of species description among North American and Australian reptiles and amphibians? Global Ecology and Biogeography 11(1): 41-47.

Štastný, J. 2003: Dytiscidae: X. Review of Platynectes subgen. Gueorguievtes Vazirani from Southeast Asia (Coleoptera). In: Water Beetles of China III (eds. Jäch, M.A. and Li, J.). 217-259

White, R.E. 1979. Response to the Use of Trend Curves by Erwin, Frank and Curtis, and O'Brien and Wibmer. The Coleopterists Bulletin 33(2): 167-168.

Ødegaard, F. 2000. How many species of arthropods? Erwin's estimate revised. Biological Journal of the Linnean Society 71: 583-597.

\section{REVISIONS ANALYZED}

Anderson, R.D. 1971. A Revision of the Nearctic Representatives of Hygrotus (Coleoptera: Dytiscidae). Annals of the Entomological Society of America 64: 503-512.

Anderson, R.D. 1983. Revision of the Nearctic species of Hygrotus groups 4, 5, and 6 (Coleoptera: Dytiscidae), Annals of the Entomological Society of America 76(2) 173196.

Angus, R.B., Fresneda, J. and Fery, H. 1992. A revision of the Nebrioporus carinatus species complex (Coleoptera, Dytiscidae). Nouvelle Revue d'Entomologie 9(4) 287-303.

Balke, M. 1995. Revision of the AfrotropicalOriental Rhantus rugulosus-clade (Coleoptera: Dytiscidae). Entomologica Scandinavica 26(2) 229-239.

Balke, M. 1998. Revision of New Guinea Copelatus Erichson, 1832 (Insecta: Coleoptera: Dytiscidae): The running water species, Part I. Annalen des Naturhistorischen Museum in Wien (B) 100: 301 341.
Balke, M. 2001. Biogeography and classification of New Guinean Colymbetini (Coleoptera: Dytiscidae: Colymbetinae). Invertebrate Taxonomy 15: 259-275.

Balke, M., Larson, D.J., and Hendrich, L. 1997. A review of the New Guinea species of Laccophilus Leach 1815 with notes on regional melanism (Coleoptera Dytiscidae). Tropical Zoology 10: 295-320.

Balke, M., Larson, D.J., Hendrich, L., and Konyorah, E. 2000. A revision of the New Guinea water beetle genus of Philaccolilus Guignot, stat. n. (Coleoptera Dytiscidae). Mitteilungen aus dem Museum für Naturkunde Berlin, Deutsche Entomologische Zeitung 47: 29-50.

Bergsten, J., and Miller, K.B. 2006. Taxonomic revision of the holarctic diving beetle genus Acilius Leach (Coleoptera: Dytiscidae). Systematic Entomology 31: 145-197.

Biström, O. 1979. A revision of the genus Derovatellus Sharp (Coleoptera, Dytiscidae) in Africa. Acta Entomologica Fennica 35: 1- 28.

Biström, O. 1982. A revision of the genus Hyphydrus Illiger (Coleoptera, Dytiscidae). Acta Zoologica Fennica 165: 1-121.

Biström, O. 1983. Revision of the genera Yola Des Gozis and Yolina Guignot (Coleoptera, Dytiscidae). Acta Zoologica Fennica 176: 1-67.

Biström, O. 1985. A revision of the species group B. sharpi in the genus Bidessus (Coleoptera, Dytiscidae). Acta Zoologica Fennica 178: 1-40.

Biström, O. 1986. Review of the genus Hydroglyphus Motschulsky (= Guignotus Houlbert) in Africa (Coleoptera, Dytiscidae). Acta Zoologica Fennica 182: 1-56.

Biström, O. 1987a. Review of the genus Leiodytes in Africa (Coleoptera, Dytiscidae). Annales Entomologici Fennici 53(3): 91-101.

Biström, O. 1987b. Revision of the genus Pachynectes Regimbart (Coleoptera, Dytiscidae). Annales Entomologici Fennici 53(2) 48-52.

Biström, O. 1988a. Revision of the genus Clypeodytes Régimbart in Africa (Coleoptera: Dytiscidae). Entomologica Scandinavica 19: 199238.

Biström, O. 1988b. Review of the genus Liodessus in Africa (Coleoptera, Dytiscidae). Annales Entomologici Fennici 54: 21-28.

Biström, O. 1988c. Review of the genus Uvarus Guignot in Africa (Coleoptera, Dytiscidae). Acta Entomologica Fennica 51: 1-38.

Biström, O. 1990. Revision of the genus Queda Sharp (Coleoptera: Dytiscidae). Quaestiones Entomologicae 26(2): 211-220.

Biström, O. 1997. Taxonomic revision of the genus Hydrovatus Motschulsky (Coleoptera, Dytiscidae). Entomologica Basiliensia 19: 57584. 
Biström, O., and Nilsson, A.N. 2002. Herophydrus Sharp: Cladistic analysis, taxonomic revision of the African species, and world check list (Coleoptera: Dytiscidae). Koleopterologische Rundschau 72: 15-111.

Biström, O. and Nilsson, A.N. 2003. Taxonomic revision and cladistic analysis of the genus Peschetius Guignot (Coleoptera: Dytiscidae). Aquatic Insects 25(2): 125-155.

Biström, O., and Nilsson, A.N. 2006. Taxonomic revision of the Ethiopian genus Canthyporus (Coleoptera Dytiscidae). Memorie della Societa Entomologica Italiana 85: 207-304.

Brancucci, M. 1983. Révision des espèces estpaléarctiques, orientales et australiennes du genre Laccophilus (Col. Dytiscidae). Entomologische Arbeiten aus dem Museum G. Frey 31-32: 241426.

Brancucci, M. 1986. Revision of the genus Lacconectus Motschulsky (Coleoptera, Dytiscidae). Entomologica Basiliensia 11: 81202.

Brancucci, M. 1988. A revision of the genus Platambus Thomson (Coleoptera, Dytiscidae). Entomologica Basiliensia 12: 165-239.

Brancucci, M. 2003. A review of the genus Lacconectus Motschulsky, 1855 from the Indian subcontinent (Coleoptera, Dytiscidae). Entomologica Basiliensia 25: 3-39.

Brancucci, M. and Hendrich, L. 2005. A review of Indomalayan Lacconectus Motschulsky, 1855 (Coleoptera: Dytiscidae: Copelatinae). Mitteilungen der Schweizerischen Entomologischen Gesellschaft 78(3-4) 265-297.

Fery, H. 1991. Revision der 'minutissimus-Gruppe' der Gattung Bidessus Sharp (Coleoptera: Dytiscidae). Entomologica Basiliensia 14: 57-91.

Fery, H. 1992. Revision der saginatus-Gruppe der Gattung Coelambus Thomson (Coleoptera: Dytiscidae). Linzer Biologische Beitraege 24(1): 339-358.

Fery, H. 1999. Revision of a part of the memnoniusgroup of Hydroporus Clairville, 1806 (Insecta: Coleoptera: Dytiscidae) with the description of nine new taxa, and notes on other species of the genus. Annalen des Naturhistorischen Museums in Wien (B) 101: 217-269.

Fery, H. and Brancucci, M. 1997. A taxonomic revision of Deronectes Sharp, 1882 (Insecta: Coleoptera: Dytiscidae) (part I). Annalen des Naturhistorischen Museums in Wien (B) 99: 217302.

Fery, H. and Hosseinie, S.O. 1998. A taxonomic revision of Deronectes Sharp, 1882 (Insecta: Coleoptera: Dytiscidae) (part II). Annalen des Naturhistorischen Museums in Wien (B) 100: 219-290.

Fery, H. and Nilsson, A.N. 1993. A revision of the Agabus chalconatus- and erichsoni-groups
(Coleoptera: Dytiscidae), with a proposed phylogeny. Entomologica Scandinavica 24: 79108.

Hendrich, L. and Balke, M. 1997. Taxonomische Revision der südostasiatischen Arten der Gattung Neptosternus Sharp, 1882 (Coleoptera: Dytiscidae: Laccophilinae). Koleopterologische Rundschau 67: 53-97.

Hendrich, L. and Balke, M. 2000. The genus Platynectes Régimbart in the Moluccas (Indonesia): taxonomy, faunistics and zoogeography (Coleoptera: Dytiscidae). Koleopterologische Rundschau 70: 37-52.

Hendrich, L. and Wang, L. 2006. Taxonomic revision of Australian Clypeodytes (Coleoptera: Dytiscidae, Bidessini). Entomological problems 36 (1): 1-11.

Hendrich, L. and Watts, C.H.S. 2004. Taxonomic revision of the Australian genus Sternopriscus Sharp, 1882 (Coleoptera: Dytiscidae: Hydroporinae). Koleopterologische Rundschau 74: 75-142.

Hendrich, L. and Watts, C.H.S. 2009. Taxonomic revision of the Australian predaceous water beetle genus Carabhydrus Watts, 1978 (Col. Dytiscidae, Hydroporinae, Hydroporini). Zootaxa 2048: 1-30.

Larson, D.J. 1987. Revision of North American species of Ilybius Erichson (Coleoptera: Dytiscidae), with systematic notes on Palearctic species. Journal of the New York Entomological Society 95: 341-413.

Larson, D.J. 1989. Revision of North American Agabus Leach (Coleoptera: Dytiscidae): Introduction, key to species groups, and classification of the ambiguus-, tristis-, and arcticus-groups. The Canadian Entomologist 121: 861-919.

Larson, D.J. 1991. Revision of North American Agabus Leach (Coleptera: Dytiscidae): elongatus, zetterstedti-, and confinis-groups. The Canadian Entomologist 123: 1239-1317.

Larson, D.J. 1994. Revision of North American Agabus Leach (Coleoptera: Dytiscidae): lutosus-, obsoletus-, and fuscipennis-groups. The Canadian Entomologist 126: 135-181.

Larson, D.J. 1996. Revision of North American Agabus Leach (Coleoptera: Dytiscidae): The opacus-group. The Canadian Entomologist 128: 613-665.

Larson, D.J. 1997. Revision of North American Agabus Leach (Coleoptera: Dytiscidae): The seriatus-group. The Canadian Entomologist 129: 105-149.

Larson, D.J. and Roughley, R.E. 1990. A review of the species of Liodessus Guignot of North America north of Mexico with the description of a new species (Coleoptera: Dytiscidae). Journal of the New York Entomological Society 98: 233245. 
Larson, D.J. and Wolfe, G.W. 1998. Revision of North American Agabus Leach (Coleoptera: Dytiscidae): The semivittatus-group. The Canadian Entomologist 130: 27-54.

Matta, J.F. and Wolfe, G.W. 1981. A revision of the subgenus Heterosternuta Strand of Hydroporus Clairville (Coleoptera: Dytiscidae). The PanPacific Entomologist 57: 176-219.

Miller, K.B. 1998. Revision of the Nearctic Liodessus affinis (Say 1823) species group (Coleoptera: Dytiscidae, Hydroporinae, Bidessini). Entomologica Scandinavica 29(3): 281-314.

Miller, K.B. 2001a. Revision of the Neotropical genus Hemibidessus Zimmermann (Coleoptera: Dytiscidae: Hydroporinae: Bidessini). Aquatic Insects 23(4): 253-275.

Miller, K.B. 2001b. Revision of the genus Agaporomorphus Zimmermann (Coleoptera: Dytiscidae). Annals of the Entomological Society of America 94: 520-529.

Miller, K.B. 2001c. Revision and phylogenetic analysis of the New World genus Neoclypeodytes Young (Coleoptera: Dytiscidae: Hydroporinae: Bidessini). Systematic Entomology 26: 87-123.

Miller, K.B. 2005. Revision of the New World and south-east Asian Vatellini (Coleoptera: Dytiscidae: Hydroporinae) and phylogenetic analysis of the tribe. Zoological Journal of the Linnean Society 144: 415-510.

Nilsson, A.N. 1992a. A revision of Afrotropical Agabus Leach (Coleoptera, Dytiscidae), and the evolution of tropicoalpine super specialists. Systematic Entomology 17: 155-179.

Nilsson, A.N. 1992b. A revision of the East African Nebrioporus abyssinicus group (Coleoptera, Dytiscidae). Entomologica Fennica 3(2) 81-93.

Nilsson, A.N. 1994a. Revision of the Hydroporus nigellus complex (Coleoptera: Dytiscidae) including multivariate species separation. Entomologica Scandinavica 25(1): 89-104.

Nilsson, A.N. 1994b. A revision of the Palearctic Ilybius crassus-complex (Coleoptera, Dytiscidae). Entomologisk Tidskrift 115(1-2): 55-61.

Nilsson, A.N. 1997. A redefinition and revision of the Agabus optatus-group (Coleoptera, Dytiscidae); an example of Pacific intercontinental disjunction. Entomologica Basiliensia 19: 621-651.

Nilsson, A.N. 1998. Dytiscidae: V. The genus Platynectes Regimbart in China, with a revision of the dissimilis-complex (Coleoptera). In: Water Beetles of China III (eds. Jäch, M.A. and Li, J.). 107-121.

Nilsson, A.N. and Larson, D.J. 1990. A review of the Agabus affinis group (Coleoptera: Dytiscidae), with the description of a new species from Siberia and a proposed phylogeny. Systematic Entomology 15(2): 227-239.
Nilsson, A.N. and Nakane, T. 1993. A revision of the Hydroporus species (Coleoptera: Dytiscidae) of Japan, the Kuril Islands, and Sakhalin. Entomologica Scandinavica 23(4): 419-428.

Roughley, R.E. 1990. A systematic revision of species of Dytiscus Linnaeus (Coleoptera: Dytiscidae). Part 1. Classification based on adult stage. Quaestiones Entomologicae 26: 383-557.

Satô, M. 1985. The genus Copelatus of Japan (Coleoptera: Dytiscidae). Transactions of the Shikoku Entomological Society 17: 57-67.

Štastný, J. 2003: Dytiscidae: X. Review of Platynectes subgen. Gueorguievtes Vazirani from Southeast Asia (Coleoptera). In: Water Beetles of China III (eds. Jäch, M.A. and Li, J.). 217-259

Shaverdo, H.V. 2004. Revision of the nigrita-group of Hydroporus Clairville, 1806 (Insecta: Coleoptera: Dytiscidae). Annalen des Naturhistorischen Museums in Wien (B) 105: 217-263.

Shaverdo, H.V. 2006. Revision of the longiusculusgroup of the genus Hydroporus Clairville, 1806 (Coleoptera: Dytiscidae). Zootaxa 1170: 27-56.

Shirt, D.B. and Angus, R.B. 1992. A revision of the Nearctic water beetles related to Potamonectes depressus (Fabricius) (Coleoptera: Dytiscidae). Coleopterists Bulletin 46(2): 109-141.

Toledo, M. 2009. Revision in part of the genus Nebrioporus Regimbart, 1906, with emphasis on the N. laeviventris-group (Coleoptera: Dytiscidae). Zootaxa 2040: 1-111.

Trémouilles, E.R. 1996. Revisión del género Hydaticus Leach en América del sur, con descripción de tres nuevas especies (Coleoptera, Dytiscidae). Physis, secc. B52: 15-32.

Watts, C.H.S. 2000. Three new species of Tiporus Watts (Coleoptera: Dytiscidae) with redescriptions of the other species in the genus. Records of the South Australian Museum 33: 8999.

Watts, C.H.S. and Leys, R. 2008. Review of the epigean species of Paroster Sharp, 1882, with descriptions of three new species, and phylogeny based on DNA sequence data of two mitochondrial genes (Coleoptera: Dytiscidae: Hydroporinae). Koleopterologische Rundschau 78: 9-36.

Wewalka, G. 1979. Revision der Artengruppe des Hydaticus (Guignotites) fabricii (Mac Leay), (Col., Dytiscidae). Koleopterologische Rundschau 54: 119-139.

Wewalka, G. 1980. Revision der afrikanischen Gattung Heterhydrus Fairm. (Coleoptera, Dytiscidae). Annales Historico-Naturales Musei Nationalis Hungarici 72: 97-101.

Wewalka, G. 1997. Taxonomic revision of Microdytes Balfour-Browne (Coleoptera: Dytiscidae). Koleopterologische Rundschau 67: 13-51. 


\section{RICHNESS}

Wewalka, G. 2000. Taxonomic revision of Allopachria (Coleoptera: Dytiscidae). Entomological Problems 31: 97-128.

Wolfe, G.W. 1984. A revision of the vittatipennis species group of Hydroporus Clairville, subgenus Neoporus Guignot (Coleoptera: Dytiscidae). Transactions of the American Entomological Society 110(3): 389-433.

Wolfe, G.W.and Roughley R.E. 1990. A taxonomic phylogenetic and zoogeographic analysis of Laccornis Gozis (Coleoptera: Dytiscidae) with the description of Laccornini, a new tribe of Hydroporinae. Quaestiones Entomologicae 26: 273-354.

Young, F.N. 1981a. Predaceous water beetles of the genus Desmopachria Babington: the leechiglabricula group (Coleoptera: Dytiscidae). The Pan-Pacific Entomologist 57(1): 57-64.

Young, F.N. 1986. Review of the predaceous water beetles of the genus Bidessodes Régimbart (Coleoptera, Dytiscidae). Entomologica Basiliensia 11: 203-220.
Young, F.N. 1981c. Predaceous water beetles of the genus Neobidessus from South America (Coleoptera: Dytiscidae). The Coleopterists Bulletin 35(3): 317-340.

Young, F.N. 1981b. Predaceous water beetles of the genus Desmopachria: The convexa-grana group (Coleoptera: Dytiscidae). Occasional Papers of the Florida State Collection of Arthropods 2(IIIIV): $1-11$.

Young, F.N. 1990. Predaceous water beetles of the genus Desmopachria Babington: the subgenus Pachriostrix Guignot (Coleoptera: Dytiscidae). The Coleopterists Bulletin 44(2): 224-228.

Young, F.N. 1995. The genus Desmopachria Babington, subgenus Portmannia Young (Coleoptera: Dytiscidae). Insecta Mundi 9: 37-44.

Zimmerman, J.R. 1981. A revision of the Colymbetes of North America (Dytiscidae). The Coleopterists Bulletin 35(1): 1-52.

Zimmerman, J.R. 1985. A revision of the genus Oreodytes in North America (Coleoptera: Dytiscidae). Proceedings of the Academy of Natural Sciences of Philadelphia 137(1): 99-127. 